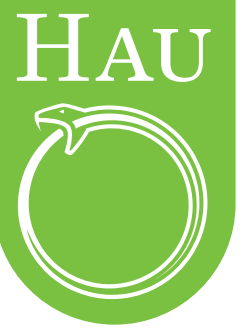

\title{
DEBATE
}

\section{Anthropology contra ethnography}

\author{
Tim IngOLD, University of Aberdeen
}

Ethnography aims to describe life as it is lived and experienced, by a people, somewhere, sometime. Anthropology, by contrast, is an inquiry into the conditions and possibilities of human life in the world. Anthropology and ethnography may have much to contribute to one another, but their aims and objectives are different. Ethnography is an end in itself; it is not a means to anthropological ends. Moreover, participant observation is an anthropological way of working, not a method of ethnographic data collection. To study anthropology is to study with people, not to make studies of them; such study is not so much ethnographic as educational. An anthropological education gives us the intellectual means to speculate on the conditions of human life in this world, without our having to pretend that our arguments are distillations of the practical wisdom of those among whom we have worked. Our job is to correspond with them, not to speak for them. Only by acknowledging the speculative nature of anthropological inquiry can we both make our voices heard and properly engage with other disciplines. And only then can we lead the way in forging the universities of the future.

Keywords: ethnography, anthropology, participation, observation, method, education, philosophy, art, university

Let me say, from the outset, that I have nothing against ethnography. The aim of ethnography, as I understand it, is to render an account-in writing, film, or other graphic media-of life as it is actually lived and experienced by a people, somewhere, sometime. Good ethnography is sensitive, contextually nuanced, richly detailed, and above all faithful to what it depicts. These are all admirable qualities.

What I am against, then, is not ethnography as such, but its portrayal as the beall and end-all of the discipline of anthropology. I believe this collapse of anthropology into ethnography has deflected the discipline from its proper purpose; it has hamstrung anthropological efforts to contribute to debate on the great questions of our time, and compromised its role within the academy. It is vital for the future 
of the discipline, I contend, that we stop being so evasive and come clean about the difference between anthropology and ethnography. This, of course, means being clear about the definition and purpose of the discipline of anthropology.

So here's my definition. Anthropology, I maintain, is a generous, open-ended, comparative, and yet critical inquiry into the conditions and possibilities of human life in the one world we all inhabit. It is generous because it pays attention, and responds, to what other people do and say. In our inquiries we receive in good grace what is given rather than seek by subterfuge to extract what is not, and we are at pains to give back what we owe to others for our own moral, intellectual, and practical formation. This happens, above all, in participant observation, and I shall return to this. Anthropology is open-ended because we do not seek final solutions but rather ways along which life can keep on going. We are committed in this sense to sustainable living - that is, a form of sustainability that that does not render the world sustainable for some through the exclusion of others but rather has a place for everyone and everything. Anthropology is comparative because we are aware that for any path life might take, it could have taken other paths. No path is preordained as the only one that is "natural." Thus the question, "why this way rather than that?" is always uppermost in our minds. And anthropology is critical because we cannot be content with things as they are. By general consent, the organizations of production, distribution, governance, and knowledge that have dominated the modern era have brought the world to the brink of catastrophe. In finding ways to carry on, we need all the help we can get. But no specialist science, no indigenous group, no doctrine or philosophy already holds the key to the future if only we could find it. We have to make that future together, for ourselves, and this can only be done through dialogue. Anthropology exists to expand the scope of this dialogue: to make a conversation of human life itself.

If you agree with my definition of anthropology, then I think you will also have to agree that its aims and principles are entirely different from those of ethnography. As enterprises, anthropology and ethnography may be complementary, they may have much to contribute to one another, but they are different nonetheless. I want to make it absolutely clear, however, that I do not see this difference in the way in which it was put forth, in equally uncompromising terms, by some of the founding fathers of social anthropology, and that is still upheld by some today. Their view was, and is, that ethnography is idiographic, dedicated to the documentation of empirical particulars, and that anthropology is nomothetic, dedicated to comparative generalization and the search for law-like regularities in the conduct of human affairs. The idea is that you first do your ethnographic research and then-in a subsequent stage-you convert your study into a case for comparison, placed alongside other similar studies, in the hope that some viable generalities might emerge. Every time I hear the phrase "ethnographic case study," innocently rehearsed as though it were entirely unproblematic, I wince in protest. And when the people depicted in that study are portrayed as if they belonged to the ethnographer in person-as in "Geertz's Balinese"-my wince becomes a scream! Nothing is more degrading of the spirit and purpose of ethnographic inquiry. I am sometimes accused of wanting to attack ethnography. But my aim is just the opposite. It is to defend ethnography against those who would wrap other people's lives into cases, and who see in ethnography not a worthy end in itself but merely a means to the 
end of anthropological generalization. I want to defend ethnography from those who would see it as a method. Of course, like any craft-like endeavor, ethnography has its methods-its rules of thumb, its ways of working-but it is not a method.

This brings me back to participant observation. I have already mentioned that participant observation is key to the practice of anthropology, and underwrites the generosity of its approach to attending and responding. It is a way, as I would like to put it, of corresponding with people. But I also want to insist that participant observation and ethnography are not the same. The very idea of "ethnographic fieldwork" perpetuates the notion that what you are doing in the field is gathering material on people and their lives-or what, to burnish your social scientific credentials, you might call "qualitative data" - which you will subsequently analyze and write up. That's why participant observation is so often described in textbooks as a method of data collection. And it is why so much ink has been spilled on the practical and ethical dilemmas of combining participation and observation, as though they pointed in different directions. There is something deeply troubling, as we all know, about joining with people, apparently in good faith, only later to turn your back on them so that yours becomes a study of them, and they become a case. But there is really no contradiction between participation and observation; indeed, you simply cannot have one without the other. The great mistake is to confuse observation with objectification. To observe is not, in itself, to objectify. It is to notice what people are saying and doing, to watch and listen, and to respond in your own practice. That is to say, observation is a way of participating attentively, and it is for this reason a way of learning. As anthropologists, it is what we do, and what we undergo. And we do it and undergo it out of recognition of what we owe to others for our own practical and moral education. Participant observation, in short, is not a technique of data gathering but an ontological commitment. And that commitment is fundamental to the discipline of anthropology.

The distinction between the kinds of work done with the little words of and with is all-important here. It is the of that converts observation into objectification, running rings around the beings and things that command our attention and turning them into circumscribed topics of inquiry. Thus we get the anthropology of this or that. But to practice anthropology, as I understand it, means to study with people, not to make studies of them-just as we might study with our teachers at the university. We do so in order that we may grow in wisdom and maturity, in our powers of observation, reason, and critical thinking, in the hope and expectation that we can bring these powers to bear on whatever problems we may tackle in the future. That's why participant observation should be understood, in the first place, not as ethnographic but as educational. It is a way of learning, and that learning-as we well know—can be transformative.

This carries a critical implication. An ethnographer can reasonably feel constrained in what he or she can write by the requirements of descriptive fidelity. You cannot write just anything, and what you do write needs to be justified by the claim that it is a fair representation, interpretation, or analysis of what the subjects of your inquiry do, say, or think. Nor can I write just anything as an anthropologist. But in what I write I can at least argue for what I consider to be true, or as close to the truth as I can attain, in the light of my reading, the conversations I have had, and my own critical reflection. Anthropology is nothing if not speculative, and I 
want to cherish and protect the intellectual freedom I have, as an anthropologist, to speculate on the conditions and possibilities of human life in this world. Of course I must be prepared to back up my position with reason, argument, and evidence. But I should not have to validate it by pretending that the arguments I am putting forward, and seeking to defend, are actually distillations of the views of the people among whom I have worked and studied. Indeed, I might profoundly disagree with them. Participant observation can be uncomfortable, and we certainly don't have to go into it thinking that everything the people tell us is true or wonderful. They may do or say things that we find awful or abhorrent. Our task, then, is not to mask this abhorrence with a veil of sympathy, or present an artificially sanitized account of their words and deeds, but directly to take issue with them. For in addressing the reasons why we feel as we do, we can grow in wisdom ourselves, and add strength and rigor to our own arguments.

I believe we must demand the right to speak with voices of our own, and to say what we think on the basis of our inquiries, regardless of whether it accords with the thinking of our interlocutors. We may have learned from what they have told us, but as anthropologists rather than ethnographers it is not our job to reflect it. Just like practitioners of any other discipline, we must be ready to speak with our own voices and not hide behind the voices of others. If we fail to do so, we will find ourselves excluded from the great debates of our time-debates about how we should live-or find that we are brought in only to provide the material for others to manipulate as they will. And as we know only too well, there are plenty of others of more narrow-minded, intolerant, or fundamentalist bent who are only too ready to fill the void. We anthropologists have tremendously important things to say, and we need to be there to say them. But we can only make our presence felt by dropping the pretense that we have authority to speak only as ethnographers and thus that we have nothing to say for ourselves.

Anthropology, as I have presented it, is fundamentally a speculative discipline. It is akin to philosophy in that sense, but differs from philosophy (at least as practiced by the majority of professional philosophers) in that it does its philosophizing in the world, in conversation with its diverse inhabitants rather than in arcane reflections on an already established literary canon. For that reason, I think we can do philosophy better than most philosophers who, for the most part, seem chronically out of touch with life and addicted to thought experiments with little purchase on the world. But once again, this speculative ambition distinguishes anthropology from ethnography. At the same time, it opens anthropology to many other ways of conducting its inquiries - for example through art, design, theatre, dance, and music, not to mention architecture, archaeology, and comparative history. Successful interdisciplinary collaboration with such fields as these depends precisely on the recognition that what we are doing is not ethnography. For example, while ethnography combines very well with art history, attempts to combine ethnography with art practice generally lead to bad art and bad ethnography, compromising not only the ethnographer's commitment to descriptive fidelity but also art's experimental and interventionist interrogation. But an anthropology that is experimental and interrogative can combine with art practice in highly productive ways. What is crucial about both anthropology and art practice, and what distinguishes both from ethnography and art history, is that they are not about understanding actions 
and works by embedding them in context—not about accounting for them, ticking them off, and laying them to rest-but about bringing them into presence so that we can address them, and answer to them, directly.

I want to conclude with a word about the future of anthropology in relation to the future of the university. Anthropology is a university discipline and would not survive without the harbors that universities provide it in which to berth. What is currently happening in universities thus stands to make or break the discipline. Currently, universities are succumbing to corporate neoliberalism and anthropology is on the rack. We are at risk of going down with the whole ship. I think we need to fight for the future of universities as places of tolerance, wisdom, and humanity, where ideas matter, and where people of all nations can come together peacefully to debate these ideas. But I think of this as the future for anthropology too. So my vision for the future of the anthropology is also my vision for the future of the university, and anthropology must be at the heart of it. But we will only succeed in securing a future for anthropology within the coming university if we make a clean break, once and for all, with the reduction of anthropology to an accumulation of ethnographic case studies.

\section{Anthropologie contra ethnographie}

Résumé : L’ethnographie a pour but de décrire la vie telle qu'elle est vécue et ressentie, par un groupe humain, dans un lieu, à un moment donné. L'anthropologie, au contraire, est une enquête sur les conditions et les possibilités de vie dans ce monde. Lanthropologie et l'ethnographie ont sans doute beaucoup à contribuer l'une à l'autre, mais leurs objectifs divergent. L'ethnographie est une fin en soi, ce n'est pas un moyen pour atteindre des fins anthropologiques. De plus, lobservation participante est une manière anthropologique de travailler, non pas une méthode de collection de données ethnographiques. Etudier l'anthropologie, c'est étudier avec des gens, non pas produire des études sur eux; ce type d'étude n'est pas tant ethnographique quéducatif. Une éducation anthropologique nous donne les moyens intellectuels de réfléchir aux conditions de vie humaine dans le monde, sans avoir à prétendre que nos arguments sont le distillât du sens pratique de ceux auprès de qui nous avons travaillé. Notre tâche consiste à correspondre avec eux, non pas à parler pour eux. C'est seulement en prenant conscience de la nature spéculative de l'enquête ethnographique que nous pourrons à la fois faire entendre notre discours et engager un dialogue avec d'autres disciplines. Alors seulement pourrons-nous être à l'initiative de la constructions des universités du futur.

Tim IngOLD is Chair of Social Anthropology at the University of Aberdeen. He has carried out fieldwork among Saami and Finnish people in Lapland, and has written on environment, technology, and social organization in the circumpolar North, on animals in human society, and on human ecology and evolutionary theory. His more recent work explores environmental perception and skilled practice. Ingold's current interests lie on the interface between anthropology, archaeology, art, and 
architecture. His recent books include The perception of the environment (2000), Lines (2007), Being alive (2011), Making (2013), and The life of lines (2015).

Tim Ingold

Department of Anthropology

School of Social Science

University of Aberdeen Aberdeen AB24 3QY

Scotland, UK

tim.ingold@abdn.ac.uk 